\title{
PENGARUH Trichoderma spp. DAN FUNGISIDA SINTETIS TERHADAP PERTUMBUHAN Sclerotium rolfsii DAN KETERJADIAN PENYAKIT REBAH KECAMBAH KACANG TANAH
}

\author{
Anisah Fajar Mahabbah, Titik Nur Aeny \& Tri Maryono \\ Jurusan Agroteknologi, Fakultas Pertanian Universitas Lampung \\ J1. Prof. Soemantri Brodjonegoro, No.1, Bandar Lampung, 35145 \\ Email: anisafajar91@gmail.com
}

\begin{abstract}
ABSTRAK
Kacang tanah (Arachis hypogaea L.) merupakan salah satu tanaman jenis kacang-kacangan yang penting. Produksi kacang tanah di Indonesia terus mengalami penurunan dari tahun ke tahun. Salah satu penyebab rendahnya produksi kacang tanah adalah masih rendahnya ketahanan tanaman kacang tanah terhadap penyebab penyakit rebah kecambah. Salah satu metode pengendalian rebah kecambah pada kacang tanah adalah menggunakan agen hayati. Penelitian ini bertujuan untuk mengetahui keefektifan Trichoderma spp., fungisida karbendazim dan mankozeb terhadap pertumbuhan Sclerotium rolfsii patogen rebah kecambah dan keterjadian penyakit rebah kecambah pada kacang tanah. Penelitian ini terdiri atas dua sub percobaan yaitu percobaan in vitro dan pengujian in planta. Perlakuan disusun dalam Rancangan Acak Lengkap (RAL) dengan tiga ulangan. Data yang diperoleh dianalisis dengan sidik ragam dan dilanjutkan dengan uji BNT pada taraf nyata 5\%. Hasil penelitian menunjukkan bahwa Trichoderma spp. mampu menekan pertumbuhan Sclerotium rolfsii secara in vitro maupun in planta, sedangkan perlakuan fungisida tidak dapat menekan pertumbuhan S. rolfsii.
\end{abstract}

Kata kunci : Kacang tanah, karbendazim, mankozeb, rebah kecambah, Trichoderma spp.

\section{PENDAHULUAN}

Kacang tanah (Arachis hypogaea L.) merupakan salah satu tanaman jenis kacang-kacangan yang penting selain kedelai. Tanaman ini berpotensi untuk dikembangkan karena memiliki nilai ekonomi tinggi dan peluang pasar dalam negeri yang cukup besar. Biji kacang tanah dapat digunakan langsung sebagai bahan pangan atau secara tidak langsung sebagai bahan baku industri. Brangkasan tanaman kacang tanah dapat dimanfaatkan untuk bahan pakan ternak dan pupuk hijau (Marzuki, 2007). Kandungan nutrisi biji kacang tanah antara lain berupa protein (40\%), lemak (40-50\%), karbohidrat serta vitamin (A,B,C,D,E dan K. Luas areal pertanaman dan produksi kacang tanah di Indonesia terus mengalami penurunan dari tahun ke tahun. Pada tahun 2010, diketahui bahwa luas areal pertanaman kacang tanah di berbagai provinsi di Indonesia 620.563 ha dan produksinya sekitar 779.228 ton, tahun berikutnya (2011) luasnya menurun menjadi 539.459 hektar dan produksinya 691.289 ton (BPS, 2010). Produksi kacang tanah yang terus menurun menyebabkan tidak terpenuhinya kebutuhan dalam negeri. Penurunan luas panen antara lain disebabkan masih rendahnya ketahanan tanaman kacang tanah terhadap penyebab penyakit. Salah satu penyebab penyakit yang sering mengganggu tanaman kacang tanah adalah Sclerotium rolfsii (Hayati, 2009). Sclerotium rolfsii pada tanaman kacang tanah dapat menyebabkan penyakit rebah kecambah ataupun busuk batang yang menjadi masalah penting dalam budidaya kacang tanah dan tersebar luas di Indonesia (Semangun, 2004). Secara umum penyakit rebah kecambah pada tanaman kacang tanah sulit dikendalikan, karena patogennya memiliki kemampuan bertahan hidup cukup lama di dalam tanah berbentuk sclerotia (sklerosia) meskipun tidak ada tanaman inangnya (Semangun, 1996). Pengendalian yang telah dilakukan terhadap penyakit rebah kecambah atau penyakit busuk batang ini antara lain adalah penggunaan varietas tahan, pergiliran tanaman, dan penggunaan fungisida (Semangun, 2004), tetapi hasilnya belum memuaskan. Fungisida sintetis banyak digunakan untuk mengendalikan penyakit tanaman, tetapi penggunaan yang tidak bijaksana akan menimbulkan berbagai dampak negatif seperti terjadinya resistensi patogen, terbunuhnya mikroorganisme bermanfaat serta pencemaran lingkungan (Sumartini, 2012). Oleh karena itu, untuk mengurangi dampak 
209

negatif fungisida sintetik, perlu adanya cara pengendalian alternatif yang tidak menimbulkan dampak negatif tetapi lebih efektif dari fungisida sintetik dalam menghambat pertumbuhan $S$. rolfsii. Penelitian ini bertujuan untuk mengetahui pengaruh Trichoderma spp. dan fungisida karbendazim dan mankozeb terhadap pertumbuhan $S$. rolfsii dan keterjadian penyakit rebah kecambah pada kacang tanah.

\section{BAHAN DAN METODE}

Percobaan dilakukan di Laboratorium Penyakit Tumbuhan Jurusan Agroteknologi Fakultas Pertanian Universitas Lampung. Penelitian ini dilaksanakan dari Maret sampai dengan September 2013. Percobaan disusun dalam Rancangan Acak Lengkap (RAL) dengan tiga ulangan. Penelitian ini terdiri dari dua sub percobaan. Percobaan pertama adalah pengujian in vitro kemampuan Trichoderma spp. dan fungisida dalam menghambat pertumbuhan $S$. rolfsii, yang terdiri dari enam perlakuan yaitu $T$. harzianum (P1), $T$. koningii (P2), T.viride (P3), fungisida berbahan aktif karbendazim \& mankozeb (P4), fungisida berbahan aktif arbendazim (P5), fungisida berbahan aktif mankozeb (P6). Percobaan kedua adalah pengujian in planta kemampuan Trichoderma spp. dan fungisida dalam menghambat perkembangan penyakit rebah kecambah kacang tanah yang disebabkan oleh jamur S. rolfsii. Percobaan ini terdiri dari delapan perlakuan dengan dua kontrol yaitu T. harzianum (P1), T. koningii (P2), T. viride (P3), fungisida berbahan aktif karbendazim+ mankozeb (P4), fungisida berbahan aktif arbendazim (P5), fungisida berbahan aktif mankozeb (P6), sebagai kontrol positif tanpa Trichoderma maupun fungisida (P7), sebagai kontrol negatif tanpa S. rolfsii, Trichoderma spp. dan fungisida (P8). Data yang diperoleh dianalisis dengan sidik ragam dan dilanjutkan dengan uji BNT pada taraf nyata $5 \%$.

Sclerotium rolfsii diisolasi dari tanaman kacang tanah yang menunjukkan gejala layu atau tanda penyakit berupa sclerotia. Sclerotia diambil dan didensifeksi permukaannya dengan cara merendam dalam kloroks dan aquades dengan perbandingan 1:9 selama 3 menit, selanjutnya ditumbuhkan pada media PDA. Untuk pengujian in planta biakan $S$. rolfsii disiapkan dalam bentuk suspensi. Suspensi $S$. rolfsii dibuat dengan cara menambahkan $20 \mathrm{ml}$ air steril dalam biakan S. rolfsii berumur 10 hari dalam cawan petri. Selanjutnya biakan tersebut dikeruk agar miselia $S$. rolfsii terlepas dan kemudian dipindahkan ke dalam erlenmayer dan digojok sampai tercampur rata (homogen).
Isolat Trichoderma yang digunakan merupakan isolat koleksi Klinik Tanaman Jurusan Agroteknologi Fakultas Pertanian Universitas Lampung yaitu $T$. harzianum, T. koningii, dan $T$.viride. Isolat-isolat tersebut diremajakan dan diperbanyak dalam media PDA sebelum digunakan dalam pengujian. Untuk pengujian in planta suspensi biakan Trichoderma dibuat dengan cara menambahkan $20 \mathrm{ml}$ air steril ke dalam cawan petri berisi biakan Trichoderma berumur 10 hari. Selanjutnya biakan tersebut dikeruk agar miselia Trichoderma terlepas dan dipindahkan ke dalam erlenmayer lalu digojok sampai tercampur rata (homogen).

Pengujian in vitro dilakukan dengan metode kultur ganda yaitu pada satu cawan petri ditumbuhkan dua jamur secara berlawanan, bagian belakang cawan petri dibuat garis yang saling berpotongan pada tengah cawan petri dengan menggunakan spidol permanen. Kemudian pada garis tersebut ditentukan dua titik yang berjarak 2 $\mathrm{cm}$ dari tepi secara berlawanan. Titik - titik tersebut digunakan sebagai tempat infestasi cuplikan jamur diameter $4 \mathrm{~mm}$ (Gambar 1). Untuk perlakuan yang menggunakan fungisida, aplikasi fungisida dicampurkan ke dalam media PDA kemudian dituang ke dalam cawan petri, selanjutnya media tersebut dipotong menggunakan bor gabus dengan diameter $4 \mathrm{~mm}$ dengan masingmasing konsentrasi yang digunakan yaitu campurankarbendazim dan mankozeb $0,1 \mathrm{~g} / 100 \mathrm{ml}$, karbendazim 0,375 g/100 ml, mankozeb 0,2 g/100 ml ke dalam media PDA. Trichoderma spp., fungisida, dan S. rolfsii diinfestasikan pada titik-titik tersebut.

Perlakuan dalam percobaan ini sama dengan perlakuan pada percobaan in vitro. Media tanam yang digunakan adalah tanah yang telah disterilkan dalam autoklaf. Tanah yang telah disterilkan kemudian dimasukkan dalam wadah plastik sebanyak $0,5 \mathrm{~kg} /$ wadah. Media tanam tersebut kemudian diberikan suspensi $S$. rolfsii sebanyak $20 \mathrm{ml} /$ wadah dan dicampurkan ke dalam $0,5 \mathrm{~kg}$ tanah dalam wadah plastik berukuran diameter $20 \mathrm{~cm}$ dan diinkubasi selama satu minggu dalam kondisi lembab. Setelah satu minggu, sebanyak $20 \mathrm{ml}$ suspensi masing-masing Trichoderma diaplikasikan ke setiap wadah dengan cara dicampurkan, kemudian diinkubasi lagi selama satu minggu. Setelah satu minggu benih kacang tanah ditanam 10 benih per wadah. Penyiraman dilakukan secara teratur untuk menjaga kelembaban tanah. Untuk perlakuan menggunakan fungisida, sebelum benih kacang tanah ditanam, terlebih dahulu direndam dalam larutan fungisida sesuai konsentrasi yang digunakan. Perendaman dilakukan untuk mengetahui pengaruh 


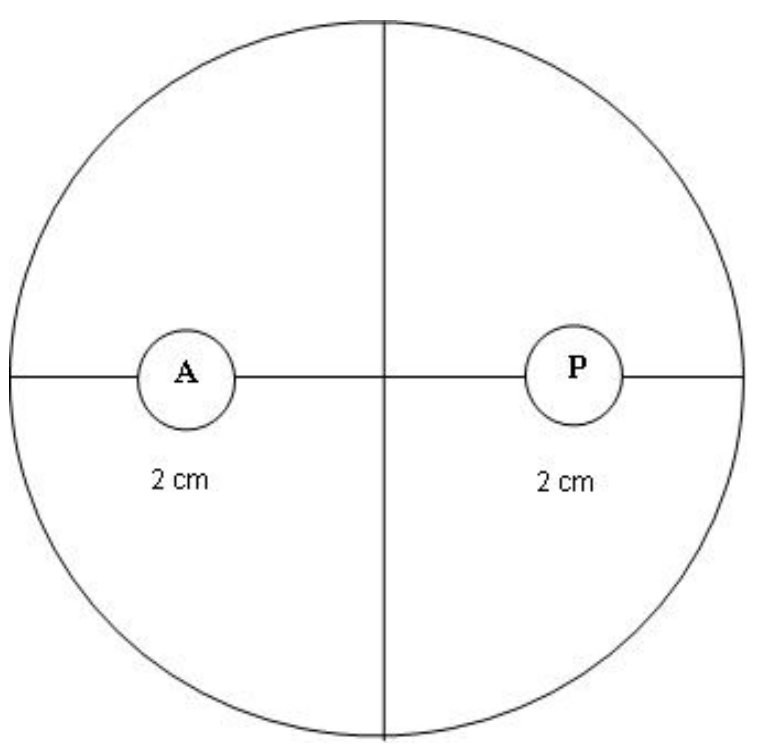

Gambar 1. Tata letak jamur Trichoderma spp. fungisida dan S. rolfsii pada uji antagonisme dalam cawan petri. ( $\mathrm{P}=$ biakan $S$. rolfsii, A = biakan Trichoderma spp. atau fungisida).

benih kacang tanah pada fase vegetatif dari serangan patogen.

Pengamatan pengujian in vitro dilakukan setiap hari mulai dari hari kedua setelah inokulasi dan dihentikan pada hari ke tujuh atau sampai pertumbuhan jamur antagonis memenuhi cawan petri. Peubah yang diamati adalah persentase penghambatan Trichoderma dan fungisida terhadap $S$. rolfsii. Persentase penghambatan Trichoderma dan fungisida dihitung dengan rumus (Muksin et al.,2013):

Keterangan :

$$
\mathrm{P}=\frac{(\mathrm{r} 1-\mathrm{r} 2)}{\mathrm{r} 1} \times 100 \%
$$

$\mathrm{P}=$ Persentase penghambatan

$\mathrm{r}_{1}=$ Jari-jari koloni patogen yang tumbuh berlawanan dengan pusat koloni antagonis $\mathrm{r}_{2}=$ Jari-jari koloni patogen yang tumbuh menuju pusat koloni antagonis.

Pada percobaan kedua, peubah yang diamati adalah jumlah tanaman yang sakit, tinggi tanaman, jumlah daun, bobot basah tanaman dan bobot kering tanaman. Pengamatan pada tinggi tanaman, jumlah daun, bobot basah dan bobot kering digunakan sebagai data penunjang untuk mengetahui efek perlakuan terhadap pertumbuhan tanaman. Bobot basah tanaman ditimbang pada 15 hsi yaitu dilakukan langsung pada saat tanaman baru dicabut dan masih segar, sedangkan bobot kering tanaman ditimbang setelah penjemuran di bawah sinar matahari selama 10 hari. Pengamatan dilakukan setiap hari selama \pm 30 hari atau sampai dengan semua tanaman pada kontrol (+) mati. Keterjadian penyakit dihitung dengan rumus:

Keterangan :

$$
\mathrm{KT}=\frac{\mathrm{n}}{\mathrm{N}} \times 100 \%
$$

$\mathrm{KT}=$ Keterjadian penyakit $(\%)$

$\mathrm{n}=$ Jumlah tanaman yang sakit

$\mathrm{N}=$ Jumlah tanaman yang diamati

\section{HASIL DAN PEMBAHASAN}

Hasil pengamatan menunjukkan bahwa pada hari pertama setelah inokulasi semua perlakuan dapat menghambat pertumbuhan Sclerotium rolfsii meskipun persentase penghambatan antara satu perlakuan dengan perlakuan lainnya tidak berbeda nyata (Tabel 1). Selanjutnya, pada pengamatan 3,5 dan 7 hari setelah inkubasi hanya perlakuan Trichoderma spp. saja yang dapat menghambat pertumbuhan Sclerotium rolfsii sedangkan perlakuan fungisida tidak dapat menekan pertumbuhan S. rolfsii (Tabel 1, Gambar 2). Hal ini menunjukkan bahwa Trichoderma spp. yang digunakan mempunyai kemampuan antagonis. Mekanisme antagonis Trichoderma spp. dapat terjadi melalui empat cara yaitu, kompetisi, antibiosis, lisis, dan mikoparasit (Harman dan Kubicek, 1998). Kompetisi ruang terjadi, yaitu kecepatan tumbuh Trichoderma spp. yang lebih cepat dari S. rolfsii menyebabkan Trichoderma spp. lebih cepat memenuhi ruang di dalam cawan petri, sehingga ruang untuk pertumbuhan $S$. rolfsii menjadi berkurang. Mekanisme antibiosis terlihat dengan adanya 
Tabel 1. Persentase penghambatan pertumbuhan Sclrotium rolfsii oleh Trichoderma spp. dan fungisida secara in vitro.

\begin{tabular}{lcccc}
\hline \multirow{2}{*}{ Perlakuan } & \multicolumn{4}{c}{ Persentase penghambatan $(\%)$} \\
\cline { 2 - 5 } & $1 \mathrm{hsi}$ & $3 \mathrm{hsi}$ & $5 \mathrm{hsi}$ & $7 \mathrm{hsi}$ \\
\hline T. harzianum & $14,81 \mathrm{a}$ & $23,53 \mathrm{a}$ & $23,53 \mathrm{a}$ & $23,53 \mathrm{a}$ \\
T. koningii & $7,41 \mathrm{a}$ & $23,80 \mathrm{a}$ & $24,97 \mathrm{a}$ & $24,97 \mathrm{a}$ \\
T. viride & $6,67 \mathrm{a}$ & $23,38 \mathrm{a}$ & $23,38 \mathrm{a}$ & $23,38 \mathrm{a}$ \\
Karbendazim \& mankozeb & $4,17 \mathrm{a}$ & $0,00 \mathrm{~b}$ & $0,00 \mathrm{~b}$ & $0,00 \mathrm{~b}$ \\
karbendazim & $12,17 \mathrm{a}$ & $0,00 \mathrm{~b}$ & $0,00 \mathrm{~b}$ & $0,00 \mathrm{~b}$ \\
mankozeb & $10,83 \mathrm{a}$ & $0,00 \mathrm{~b}$ & $0,00 \mathrm{~b}$ & $0,00 \mathrm{~b}$ \\
\hline BNT 0,05 & 9,51 & 8,36 & 8,68 & 8,68 \\
\hline
\end{tabular}

Keterangan : Angka-angka yang diikuti huruf yang sama menunjukkan tidak berbeda nyata berdasarkan uji BNT 5\%, hsi $=$ hari setelah inokulasi.
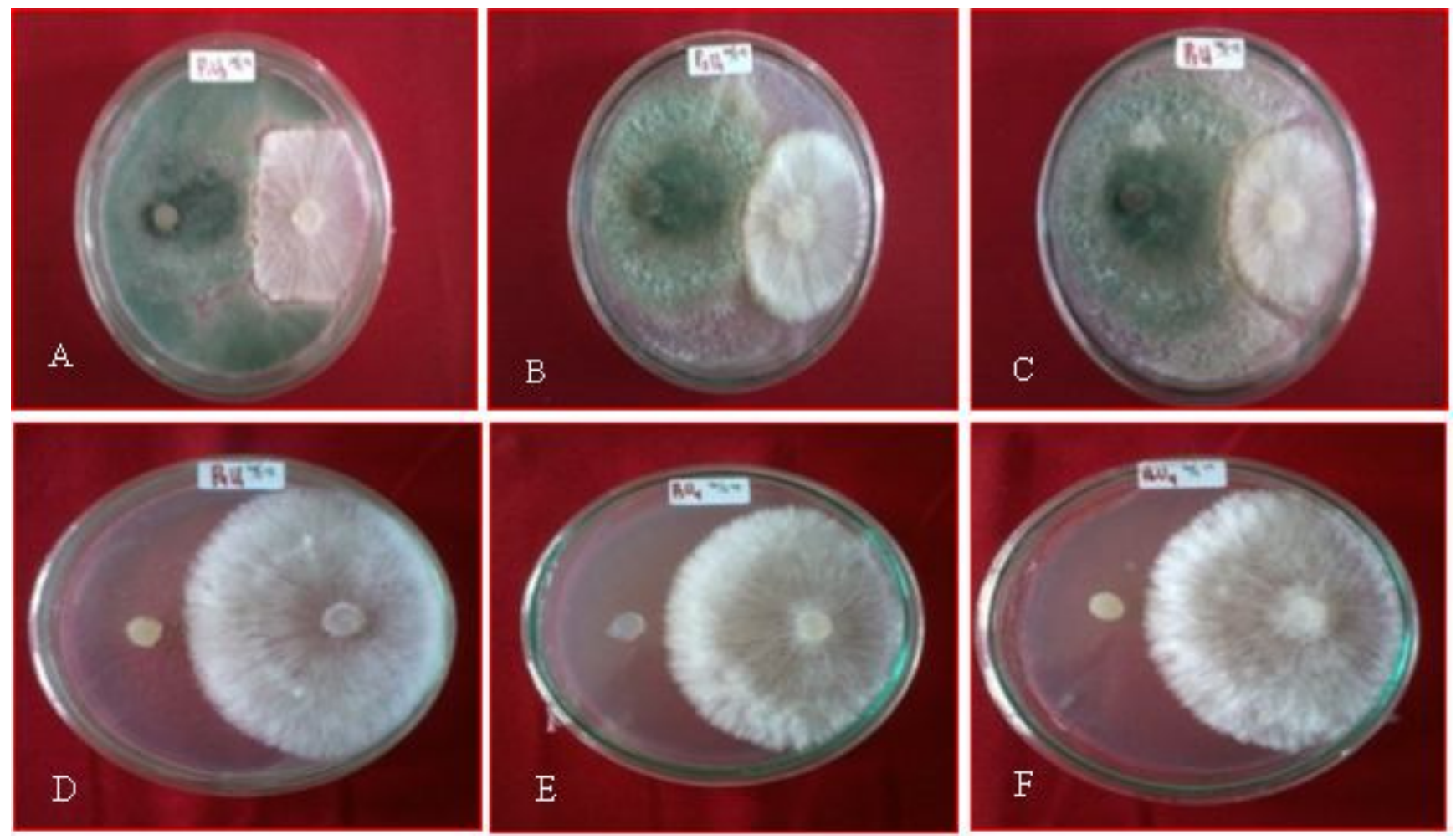

Gambar 2. Pertumbuhan koloni S. rolfsii 3 hari setelah infestasi pada berbagai perlakuan, (A) T. harzianum, (B) T. koningii, (C) T. viride, (D) karbendazim dan mankozeb, (E) karbendazim, (F) mankozeb.

zona bening di antara Trichoderma spp. dan S. rolfsii. Sclerotium rolfsii berhenti tumbuh pada zona tersebut, hal ini diduga adanya suatu senyawa yang menghalangi S. rolfsii tumbuh kearah Trichoderma spp. mikoparasit terlihat tumbuh hifa Trichoderma spp. di atas biakan $S$. rolfsii (Gambar 4).

Keefektifan jamur Trichoderma spp. dan fungisida dalam mengendalikan penyakit rebah kecambah diamati berdasarkan keterjadian penyakit pada setiap perlakuan. Hanya aplikasi Trichoderma spp. yang efektif menekan keterjadian penyakit rebah kecambah sampai dengan $0 \%$ (Tabel 2, Gambar 3). Hasil pengamatan gejala rebah kecambah pada 3 sampai 7 hsi menunjukkan bahwa pada perlakuan ketiga spesies Trichoderma spp. yang berbeda, keterjadian penyakit sebesar $0 \%$ atau semua tanamannya sehat, sama seperti pada kontrol negatif. Hal ini menunjukkan bahwa penggunaan agensi hayati mampu melindungi tanaman dari serangan patogen.

Hasil pengamatan pada 8 hsi sampai 14 hsi menunjukkan bahwa perlakuan Trichoderma spp. meningkatkan tinggi tanaman, sedangkan aplikasi 
Tabel 2. Keterjadian penyakit persentase rebah kecambah

\begin{tabular}{lccccc}
\hline \multirow{2}{*}{ Perlakuan } & \multicolumn{5}{c}{ Keterjadian penyakit (\%) } \\
\cline { 2 - 6 } & $3 \mathrm{hsi}$ & $4 \mathrm{hsi}$ & $5 \mathrm{hsi}$ & $6 \mathrm{hsi}$ & $7 \mathrm{hsi}$ \\
\hline T. harzianum & $0,00 \mathrm{c}$ & $0,00 \mathrm{~d}$ & $0,00 \mathrm{~d}$ & $0,00 \mathrm{~d}$ & $0,00 \mathrm{~b}$ \\
T. koningii & $0,00 \mathrm{c}$ & $0,00 \mathrm{~d}$ & $0,00 \mathrm{~d}$ & $0,00 \mathrm{~d}$ & $0,00 \mathrm{~b}$ \\
$T$. viride & $0,00 \mathrm{c}$ & $0,00 \mathrm{~d}$ & $0,00 \mathrm{~d}$ & $0,00 \mathrm{~d}$ & $0,00 \mathrm{~b}$ \\
Karbendazim \& mankozeb & $30,00 \mathrm{~b}$ & $53,33 \mathrm{~b}$ & $76,67 \mathrm{ab}$ & $83,33 \mathrm{c}$ & $100,00 \mathrm{a}$ \\
karbendazim & $26,67 \mathrm{~b}$ & $46,67 \mathrm{c}$ & $66,67 \mathrm{c}$ & $90,00 \mathrm{a}$ & $97,00 \mathrm{a}$ \\
mankozeb & $36,67 \mathrm{a}$ & $50,00 \mathrm{bc}$ & $73,33 \mathrm{~b}$ & $86,67 \mathrm{~b}$ & $100,00 \mathrm{a}$ \\
kontrol positif & $26,67 \mathrm{~b}$ & $76,67 \mathrm{a}$ & $80,00 \mathrm{a}$ & $90,00 \mathrm{a}$ & $100,00 \mathrm{a}$ \\
kontrol negatif & $0,00 \mathrm{c}$ & $0,00 \mathrm{~d}$ & $0,00 \mathrm{~d}$ & $0,00 \mathrm{~d}$ & $0,00 \mathrm{~b}$ \\
\hline BNT 0,05 & 4,99 & 4,99 & 3,53 & 2,88 & 2,04 \\
\hline
\end{tabular}

Keterangan : Angka-angka yang diikuti huruf yang sama menunjukkan tidak berbeda nyata berdasarkan uji BNT $5 \%$, hsi = hari setelah inokulasi.
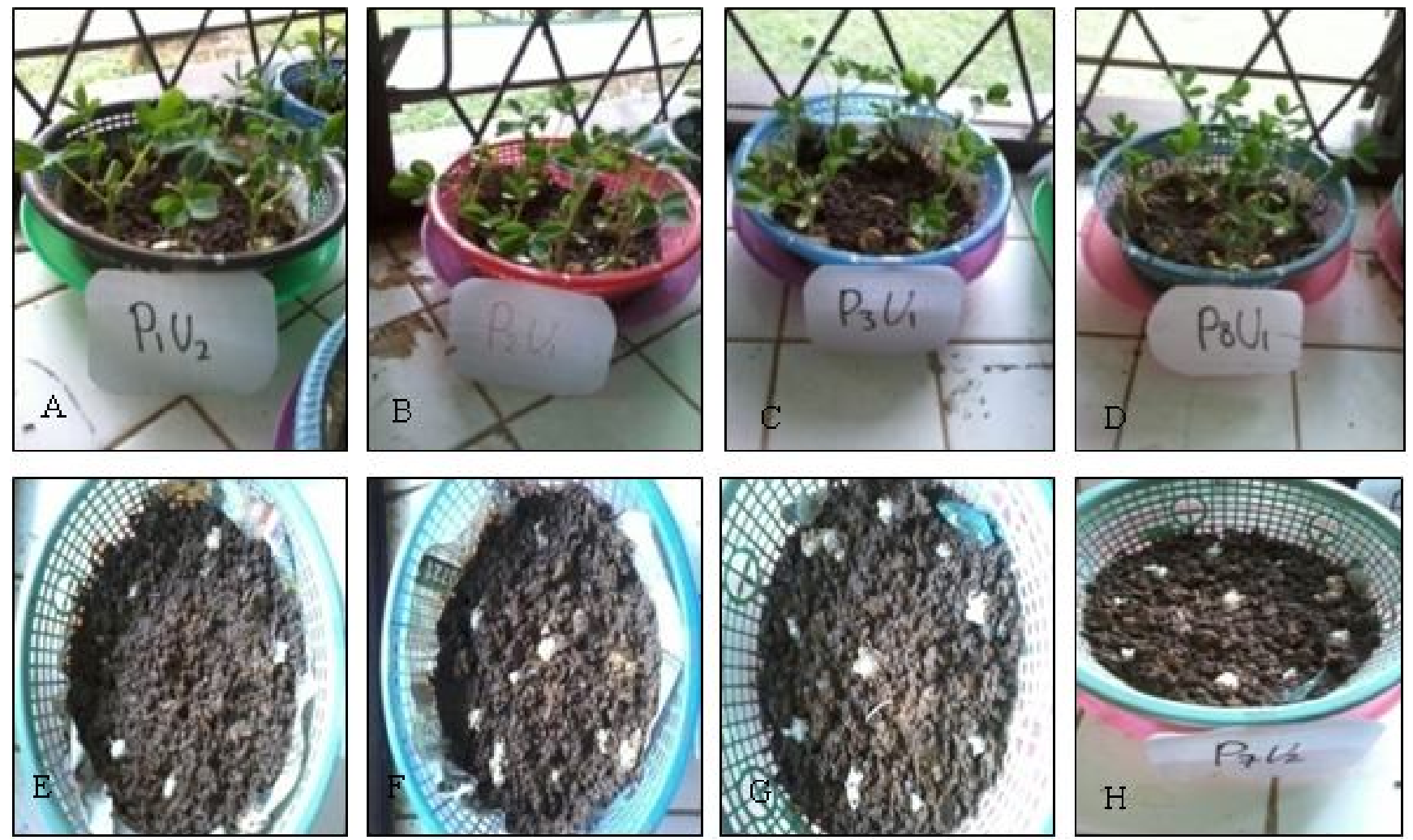

Gambar 3. Pertumbuhan benih kacang tanah setelah perlakuan Trichoderma spp. dan Fungisida (A) T. harzianum, (B) T. koningii, (C) T. viride, (D) tanpa S. rolfsii Trichoderma spp. dan fungisida, (E)karbendazim dan mankozeb, (F) karbendazim, (G) mankozeb, (H) tanpa Trichoderma spp. dan fungisida Trichoderma spp. dan fungisida.

fungisida tidak meningkatkan tinggi tanaman karena semua benih terserang $S$. rolfsii dan mati. Di antara ketiga spesies Trichoderma spp. yang digunakan, $T$. harzianum dan T. koningii menunjukkan tinggi tanaman lebih tinggi dibandingkan perlakuan T. viride (Tabel 3).

Hasil pengamatan pada 8 - 14 hsi menunjukkan bahwa perlakuan Trichoderma spp. dapat meningkatkan jumlah daun, sedangkan aplikasi fungisida tidak dapat meningkatkan jumlah daun karena semua benih terserang Sclerotium rolfsii dan mati (Tabel 4).

Hasil pengamatan terhadap bobot basah dan bobot kering brangakasan menunjukkan bahwa aplikasi spesies Trichoderma yang berbeda tidak mempengaruhi bobot basah maupun bobot kering brangkasan (Tabel 


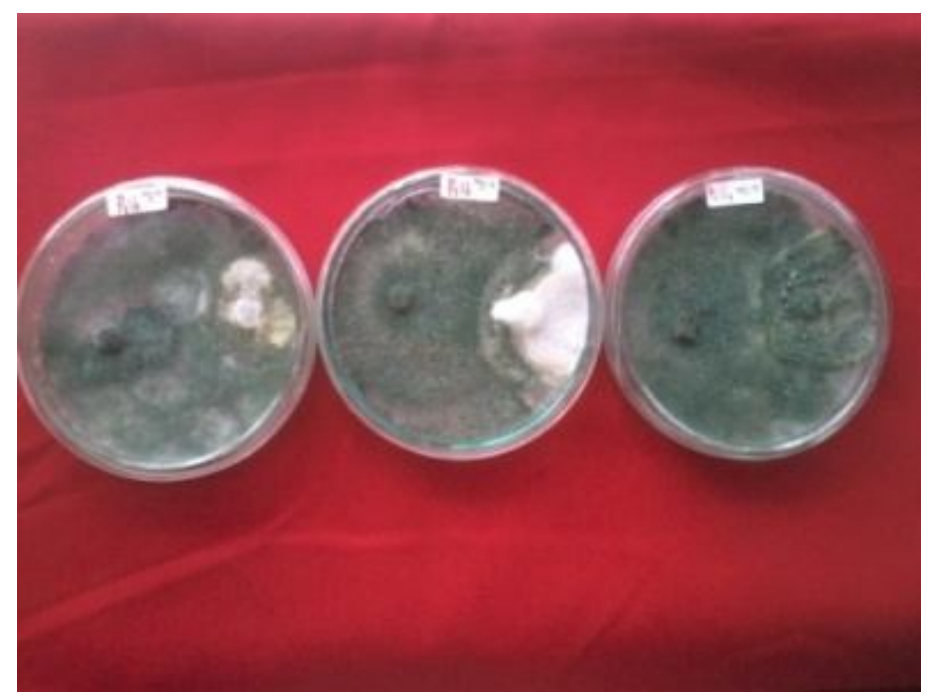

Gambar 4. Mikoparasitisme Trichoderma spp. pada Sclerotium rolfsii.

Tabel 3. Tinggi tanaman kacang tanah setelah perlakuan Trichoderma spp. dan fungisida

\begin{tabular}{lcccc}
\hline \multirow{2}{*}{ Perlakuan } & \multicolumn{4}{c}{ Tinggi tanaman $(\mathrm{cm})$} \\
\cline { 2 - 5 } & $8 \mathrm{hsi}$ & $10 \mathrm{hsi}$ & $12 \mathrm{hsi}$ & $14 \mathrm{hsi}$ \\
\hline T. harzianum & $3,07 \mathrm{a}$ & $4,66 \mathrm{a}$ & $14,33 \mathrm{a}$ & $18,20 \mathrm{a}$ \\
T. koningii & $3,53 \mathrm{~b}$ & $4,97 \mathrm{a}$ & $14,79 \mathrm{a}$ & $19,12 \mathrm{a}$ \\
T. viride & $2,95 \mathrm{~b}$ & $4,17 \mathrm{~b}$ & $11,35 \mathrm{~b}$ & $15,73 \mathrm{~b}$ \\
Karbendazim \& mankozeb & $0,00 \mathrm{c}$ & $0,00 \mathrm{c}$ & $0,00 \mathrm{~d}$ & $0,00 \mathrm{~d}$ \\
karbendazim & $0,00 \mathrm{c}$ & $0,00 \mathrm{c}$ & $0,00 \mathrm{~d}$ & $0,00 \mathrm{~d}$ \\
mankozeb & $0,00 \mathrm{c}$ & $0,00 \mathrm{c}$ & $0,00 \mathrm{~d}$ & $0,00 \mathrm{~d}$ \\
kontrol positif & $0,00 \mathrm{c}$ & $0,00 \mathrm{c}$ & $0,00 \mathrm{~d}$ & $0,00 \mathrm{~d}$ \\
kontrol negatif & $2,90 \mathrm{~b}$ & $3,97 \mathrm{~b}$ & $9,37 \mathrm{c}$ & $13,30 \mathrm{c}$ \\
\hline BNT 0,05 & 0,43 & 0,34 & 0,83 & 0,96 \\
\hline
\end{tabular}

Keterangan : Angka-angka yang diikuti huruf yang sama menunjukkan tidak berbeda nyata berdasarkan uji BNT $5 \%$, hsi $=$ hari setelah inokulasi.

Tabel 4. Jumlah daun kacang tanah setelah perlakuan Trichoderma spp. dan fungisida

\begin{tabular}{lcccc}
\hline \multirow{2}{*}{ Perlakuan } & \multicolumn{4}{c}{ Jumlah daun } \\
\cline { 2 - 5 } & $8 \mathrm{hsi}$ & $10 \mathrm{hsi}$ & $12 \mathrm{hsi}$ & $14 \mathrm{hsi}$ \\
\hline T. harzianum & $2,00 \mathrm{ab}$ & $3,13 \mathrm{a}$ & $4,77 \mathrm{~b}$ & $6,17 \mathrm{~b}$ \\
$T$. koningii & $2,13 \mathrm{a}$ & $3,20 \mathrm{a}$ & $5,10 \mathrm{a}$ & $6,40 \mathrm{a}$ \\
$T$. viride & $1,90 \mathrm{ab}$ & $2,90 \mathrm{~b}$ & $4,70 \mathrm{~b}$ & $6,13 \mathrm{~b}$ \\
Karbendazim \& mankozeb & $0,00 \mathrm{c}$ & $0,00 \mathrm{c}$ & $0,00 \mathrm{~d}$ & $0,00 \mathrm{~d}$ \\
karbendazim & $0,00 \mathrm{c}$ & $0,00 \mathrm{c}$ & $0,00 \mathrm{~d}$ & $0,00 \mathrm{~d}$ \\
mankozeb & $0,00 \mathrm{c}$ & $0,00 \mathrm{c}$ & $0,00 \mathrm{~d}$ & $0,00 \mathrm{~d}$ \\
kontrol positif & $0,00 \mathrm{c}$ & $0,00 \mathrm{c}$ & $0,00 \mathrm{~d}$ & $0,00 \mathrm{~d}$ \\
kontrol negatif & $1,87 \mathrm{~b}$ & $2,87 \mathrm{~b}$ & $4,47 \mathrm{c}$ & $5,37 \mathrm{c}$ \\
\hline BNT 0,05 & 0,25 & 0,19 & 0,21 & 0,10 \\
\hline
\end{tabular}

Keterangan : Angka-angka yang diikuti huruf yang sama menunjukkan tidak berbeda nyata berdasarkan uji BNT 5\%, hsi $=$ hari setelah inokulasi 
Tabel 5. Bobot basah brangkasan kacang tanah setelah perlakuan Trichoderma spp. dan fungisida.

\begin{tabular}{lcc}
\hline \multicolumn{1}{c}{ Perlakuan } & Bobot basah $(\mathrm{g})$ & Bobot kering $(\mathrm{g})$ \\
\hline T. harzianum & $35,87 \mathrm{~b}$ & $4,50 \mathrm{a}$ \\
T. koningii & $42,13 \mathrm{a}$ & $4,60 \mathrm{a}$ \\
T. viride & $35,83 \mathrm{~b}$ & $4,47 \mathrm{a}$ \\
Karbendazim \& mankozeb & $0,00 \mathrm{c}$ & $0,00 \mathrm{~b}$ \\
Karbendazim & $0,00 \mathrm{c}$ & $0,00 \mathrm{~b}$ \\
mankozeb & $0,00 \mathrm{c}$ & $0,00 \mathrm{~b}$ \\
kontrol positif & $0,00 \mathrm{c}$ & $0,00 \mathrm{~b}$ \\
kontrol negatif & $35,37 \mathrm{~b}$ & $4,43 \mathrm{a}$ \\
\hline BNT 0,05 & 2,41 & 0,24 \\
\hline
\end{tabular}

Keterangan : Angka-angka yang diikuti huruf yang sama menunjukkan tidak berbeda nyata berdasarkan uji BNT 5\%, hsi = hari setelah inokulasi

5). Secara umum pengamatan terhadap aspek agronomi merupakan sebagai data penunjang untuk melihat pertumbuhan tanaman kacang tanah setelah perlakuan Trichoderma spp. dan fungisida. Hasil pengamatan menunjukkan bahwa pada aplikasi Trichoderma spp. tinggi tanaman, jumlah daun, bobot basah, dan bobot kering brangkasan lebih tinggi dibandingkan dengan kontrol. Hasil ini sejalan dengan laporan Harman et al (2004a) yang menunjukan bahwa aplikasi Trichoderma spp. dalan tanah dapat meningkatkan pertumbuhan tanaman. Kolonisasi Trichoderma spp. pada akar dapat meningkatkan penyerapan nutrisi yang dibutuhkan oleh tanaman, seperti $\mathrm{P}, \mathrm{Fe}, \mathrm{Cu}, \mathrm{Mn}$, dan Zn. Selain itu, Jamur ini mampu menyelubungi sepanjang permukaan akar, mengoloni perakaran tanaman, dan meningkatkan berat kering dan segar akar dan bagian tanaman lainnya (Soesanto, 2008).

\section{KESIMPULAN}

Dari hasil penelitian ini dapat disimpulkan bahwa Trichoderma spp. dapat menekan pertumbuhan Sclerotium rolfsii secara in vitro maupun in planta, dan meningkatkan pertumbuhan tanaman (tinggi tanaman, jumlah daun, bobot basah, bobot kering). Fungisida berbahan aktif karbendazim $(0,375 \mathrm{~g} / 100 \mathrm{ml}$, mankozeb $(0,2 \mathrm{~g} / 100 \mathrm{ml})$, dan gabungannya $(0,1 \mathrm{~g} / 100 \mathrm{ml})$ tidak dapat menekan pertumbuhan Sclerotium rolfsii secara in vitro maupun in planta.

\section{DAFTAR PUSTAKA}

Badan Pusat Statistik. 2010. Produksi tanaman pangan/ Kacang tanah/ tersedia pada www.bps.go.id diakses pada 3 Februauri 2013.
Harman, G. E. \& C. P. Kubicek. (1998). Trichoderma and Gliocladium, Vol. 2.Enzymes, Biological Control and Commercial Applications. Taylor and Francis, London, UK.

Harman, G. E., C. R. Howell, A. Viterbo, I. Chet \& M. Lorito. (2004a). Trichoderma species opportunistic, avirulent plant symbionts. Nature Rev. Microbiol. 2:43-56.

Hayati, I. 2009. Evaluasi penyakit rebah kecambah pada kacang tanah Yang diaplikasikan inokulum Sclerotium rolfsii sacc. Pada berbagai konsentrasi. Jurnal Agronomi. (13)1 : 33-37.

Marzuki, R. 2007. Bertanam Kacang Tanah. Jakarta : Penebar Swadaya.

Muksin, R. Rosmini, \& J. Panggeso. 2013. Uji Antagonisme Trichoderma sp. Terhadap Jamur Patogen Alternaria porri Penyebab Penyakit Bercak Ungu Pada Bawang Merah Secara In vitro. Jurnal Agrotekbis. 1(2) : 140-144.

Semangun, H. 1996. Pengantar Ilmu Penyakit Tumbuhan. UGM Press, Yogyakarta.

Semangun, H. 2004. Penyakit-penyakit Tanaman Pangan di Indonesia. UGM Press, Yogyakarta.

Soesanto, L. 2008. Pengantar Pengendalian Hayati Penyakit Tanaman. Rajawali Pers. Jakarta..

Sumartini. 2012. Penyakit Tular Tanah (Sclerotium rolfsii dan Rhizoctonia solani) Pada Tanaman Kacang-kacangan Dan Umbi-umbian serta Cara pengendaliannya. Jurnal Litbang Pertanian. 3(1) : 27-34. 